\title{
Evaluation of the use of pequi pulp flour in breaded meat
}

\section{Avaliação do uso de farinha da polpa de pequi em empanados cárneos}

\author{
Renata Nolasco Braga-Souto ${ }^{1 *}$; Thalita Cordeiro Santos ${ }^{2}$; Rafaela Pereira de Assis \\ Barbosa $^{1}$; Gabriel Sthefano Lourenço Pereira ${ }^{1}$; Elaine Erika Elizeu da Silva ${ }^{1}$; \\ Mariuze Loyanny Pereira Oliveira ${ }^{2}$; Claudia Regina Vieira ${ }^{3}$; Juliana Pinto de Lima ${ }^{3}$
}

\begin{abstract}
Highlights:
This study reports the development and characterization of an innovative meat product. Pequi flour increases the contents of proteins and lipids in the breaded. Higher yield and volume expansion are observed in breaded with pequi. Breaded with pequi have more orange and intense coloring, associated with carotenoids. Breaded with pequi have consumption potential and acceptance as common breaded.
\end{abstract}

\begin{abstract}
Processed meat foods may be associated with poor eating habits, but the aggregation of vegetable ingredients, such as pequi (Caryocar brasiliense), makes the formulations of these products healthier and more nutritious. Thus this study aimed to characterize the chemical composition of breaded chicken prepared with pequi pulp flour in breading, as well as to evaluate the technological and sensorial properties of the breaded chicken. The pequis pulp from the region of Montes Claros - MG was dehydrated to obtain flour used in predust, with substitutions of $0 \%, 25 \%, 50 \%$ and $100 \%$ of the breadcrumbs flour. Meat products were chemically evaluated for moisture, lipids, proteins, carbohydrates, and ashes, technologically with measures of specific volume, yield, color difference, chromaticity, and tone of the breaded chicken, and sensorially by the evaluation of the intention of consumption and acceptance. As a result, pequi flour added lipid and protein content, improved yield, allowed higher specific volumes, and more intense color tones to the breaded. In addition, these presented good sensorial results and without significant differences among the studied formulations. It was concluded that the use of pequi flour in the production of breaded chicken can provide nutritional and technological enrichment to these products, without adversely affecting their sensorial characteristics.
\end{abstract}

Key words: Brazilian savanna. Caryocar Brasiliense. Innovation. Nuggets. Nutritional wealth.

\section{Resumo}

Alimentos cárneos processados podem estar associados a hábitos alimentares pouco sadios, mas a agregação de ingredientes vegetais, como o pequi (Caryocar brasiliense), torna as formulações desses produtos mais saudáveis e nutritivas. Assim, este estudo objetivou caracterizar a composição química de empanados de frango preparados com farinha da polpa de pequi na camada de empanamento, bem

\footnotetext{
${ }^{1}$ Discentes do Curso de Graduação em Engenharia de Alimentos, Instituto de Ciências Agrárias, Universidade Federal de Minas Gerais, ICA/UFMG, Montes Claros, MG, Brasil. E-mail: rnb.nolasco@gmail.com; rafaela-eali@hotmail.com; gabrielsth@ ufmg.br; elaine_ek96@hotmail.com

2 Discentes do Curso de Mestrado do Programa de Pós-Graduação em Alimentos e Saúde, ICA/UFMG, Montes Claros, MG, Brasil. E-mail: cordeirothalita@yahoo.com.br; mariuzelpe@yahoo.com.br

3 Prof ${ }^{\text {as }}$ Dr $^{\text {as }}$, ICA/UFMG, Montes Claros, MG, Brasil. E-mail: crvieira@ica.ufmg.br; juliana-pinto-lima@ica.ufmg.br

* Author for correspondence
}

Received: Aug. 21, 2019 - Approved: Apr. 01, 2020 
como avaliar as propriedades tecnológicas e sensoriais dos empanados produzidos. A polpa de pequis da região de Montes Claros - MG foi desidratada para obtenção da farinha utilizada na camada de préenfarinhamento, com substituições de $0 \%, 25 \%, 50 \%$ e $100 \%$ da farinha de rosca. Os produtos cárneos foram avaliados quimicamente quanto aos teores de umidade, lipídios, proteínas, carboidratos e cinzas; tecnologicamente com medidas de volume específico, rendimento, diferença de cor, cromaticidade e tonalidade dos empanados; e sensorialmente pela avaliação da intenção de consumo e aceitação. Como resultados, a farinha de pequi acrescentou conteúdo lipídico e proteico, melhorou o rendimento, permitiu maiores volumes específicos e tonalidades de cor mais intensas aos empanados. Ademais estes apresentaram bons resultados sensoriais e sem diferenças significativas entre as formulações estudadas. Conclui-se que a utilização da farinha de pequi na produção de empanados, pode fornecer enriquecimento nutricional e tecnológico a estes produtos, sem alterar negativamente suas características sensoriais.

Palavras-chave: Caryocar brasiliense. Cerrado. Inovação. Nuggets. Riqueza nutricional.

\section{Introduction}

Pequi (Caryocar brasiliense) is a fruit native to the Brazilian Cerrado, physically characterized as a green to greenish-brown leathery epicarp fruit, an inedible external mesocarp of white color, with internally from one to four pyrenes composed of an edible mesocarp (pulp) orange-yellow and a seed or almond coated with a spiny woody endocarp (M. R. M. R. Pinto et al., 2018; Sousa, Fernandes, Alves, Freitas, \& Naves, 2011; Torres, Santana, Shinagawa, $\&$ Mancini, 2018). It is a fruit widely used in food and income generation by communities in its original biome, in addition to having ecological relevance regarding its environmental preservation (Bailão, Devilla, Conceição, \& Borges, 2015; L. C. L. Pinto et al., 2016).

The pequi pulp has a rich composition, with an emphasis on the contents of minerals, fibers, ascorbic acid, carotenoids, phenolic compounds and fatty acids. In relation to minerals, the pulp can be considered, according to Brazilian legislation (Resolução n 269, 2005; Resolução n 54, 2012), with high contents of zinc, magnesium, and copper, as well as being a source of phosphorus and iron (Alves, Fernandes, Sousa, Naves, \& Naves, 2014; Gonçalves, Boas, Resende, Machado, \& Boas, 2011). It is also worth mentioning a high content of dietary fibers in the pequi pulp (Lima, Silva, Trindade, Torres, \& Mancini, 2007; Cardoso, Reis, Hamacek, \& Pinheiro-Sant'ana, 2013; Ribeiro,
Fernandes, Alves, \& Naves, 2014), which are known to be beneficial for gastrointestinal health and in the control of obesity, diabetes and blood pressure (Anderson et al., 2009; Klosterbuer, Roughead, \& Stavin, 2011).

Pequis ranging from 48.81 to $91.89 \mathrm{mg}_{100 \mathrm{~g}^{-1}}$ ascorbic acid have been reported in the scientific literature (Gonçalves et al., 2010, 2011; L. J. Rodrigues, Boas, Paula, Pinto, \& Piccoli, 2011), values that may be higher than those reported in pineapples (52 mg $\left.100 \mathrm{~g}^{-1}\right)$, strawberries (32.60 $\mathrm{mg} 100 \mathrm{~g}^{-1}$ ) and fresh orange juice (48.6 mg 100 $\mathrm{g}^{-1}$ ) (Aschoff et al., 2015; Rodríguez, Gomes, Rodrigues, \& Fernandes, 2017; Valente, SanchesSilva, Albuquerque, \& Costa, 2014). The pulp is rich in carotenoids, such as $\beta$-carotene and $\beta$-cryptoxanthin, precursors of vitamin $\mathrm{A}$, which are represented by 514.38 RAE $100 \mathrm{~g}^{-1}$ in the cooked pulp (Cardoso et al., 2013). The fruit also contains phenolic compounds, such as gallic, ferulic, ellagic and p-coumaric acids, which are associated with carotenoids and ascorbic acid, contribute to the high antioxidant activity of the fruit (Machado, Mello, \& Hubinger, 2015; Ribeiro et al., 2014).

Furthermore, in relation to the composition of fatty acids, the pequi pulp has mostly the presence of oleic acid (L. G. Oliveira et al., 2017; Traesel et al., 2016), which is a monounsaturated fatty acid, with studies that associate the consumption of foods with high levels of oleic acid to benefits 
such as the increase in HDL-cholesterol levels in humans (Gilmore et al., 2011), aid in the prevention of metabolic disorders (Moreira et al., 2016) and heart problems (Jones et al., 2014; Thandapilly et al., 2017).

The combination of these chemical components described in the pequi pulp suggests health benefits confirmed in in vivo studies, especially in some symptoms and causes of some chronic non-communicable diseases (CNCDs). Aguilar, Queiroz, Oliveira and Oliveira (2011) fed mice from a diet supplemented with pequi pulp and these had a significant increase in high-density lipoprotein (HDL) levels. Miranda-Vilela, Pereira, Gonçalves and Grisolia (2009) investigated antiinflammatory effects, reduced blood pressure and decreased low-density lipoproteins (LDL) related to the consumption of pequi pulp in athletes. L. G. Oliveira et al. (2017) observed an improvement in cardiac function and a reduction in hepatic triglycerides in rats fed with pequi oil.

It is noteworthy that the incorporation of pequi in different food products resulted in high sensory acceptance and consumption intention (E. N. A. Oliveira, Santos, Martins, \& Bezerra, 2011; Soares et al., 2009; Souza, Alves, Brito, Lucena, \& Rufino, 2014), which suggests potential for its application in the development of new products. However, the use of this fresh fruit is limited due to its high perishability and consequently reduced postharvest life (Machado et al., 2013). In this sense, in order to increase the shelf life, facilitate storage and concentrate the fruit's nutrients, the drying and crushing process can be used to transform the pequi pulp into flour. E. F. Rodrigues, Pantoja, Soares, Nelson and Santos (2016) prepared seasoning with the pequi pulp flour, and the preferred formulation was the one that contained the greatest amount of pequi flour (80\%). Mendonça et al. (2017) showed good ascorbic acid and carotenoid retention in the pequi pulp after vacuum drying and at low temperature.
The Pesquisa Nacional de Saúde (Instituto Brasileiro de Geografia e Estatística [IBGE], 2014) revealed that $37 \%$ of the interviewed Brazilians regularly consumed red meat and chicken containing an excess of low-quality fatty tissues, wich is related to the development of NCDs (IBGE, 2014; Claro et al., 2015). From this perspective, there are studies that seek to elaborate, improve, and evaluate some foods with a focus on healthiness (Coutinho et al., 2014; L. A. Oliveira, Reis, Santana, Santos, \& Carvalho, 2017; Silva et al., 2014). In addition to the previous example, fast food and ultra-processed foods, such as some industrialized meat products with excess sodium and saturated fats, are often chosen by the consumer, which can compromise the individual's health in the long term. (Dishchekenian et al., 2011; Eilat-Adar, Sinai, Yosefy, \& Henkin, 2013; Rouhani, Salehi-Abargouei, Surkan, \& Azadbakht, 2014).

In view of this scenario, the concern for healthy eating has grown in view of the association of health problems with the exacerbated consumption of industrialized foods, which are low in nutrients and without compounds or functional ingredients. In an attempt to reverse this scenario, some research is being developed to produce healthier quick meals products, without, however, greatly affecting their technological quality. In this theme, the following studies were carried out: breaded chicken with grape seed flour in batter (Cagdas \& Kumcuoglu, 2015); breaded chicken produced with dehydrated carrot bagasse incorporated into the breading (Kumar, Tanwar, Pandey, Shukla, \& Sharma, 2017), use of amaranth flour in the different breading layers and incorporated into the chicken meat emulsion (Tamsen, Shekarchizadeh, \& Soltanizadeh, 2018); application of fructooligosaccharides, oat bran and inulin in beef hamburgers (Angiolillo, Conte, \& Del Nobile, 2015); and breaded with partial substitution of goat meat with crushed almonds (Rajkumar, Das, \& Verma, 2014). 
Based on pequi features and the need to create healthy foods and with attributes that please the consumer, this research aimed to carry out the chemical characterization of breaded chicken prepared with pequi pulp flour in the breaded layer (predust) as well as to evaluate the technological and of the breads produced. It should also be noted that the idea of this proposal has not been found in the scientific literature until now, which reinforces its originality.

\section{Material and Methods}

The research was carried out at the Instituto de Ciências Agrárias (ICA) of the Universidade Federal de Minas Gerais (UFMG), and the pequis used in the study came from the 2016/2017 harvest in the municipality of Montes Claros (MG), Brazil.

\section{Development of pequi flour}

Completely ripe fruits with good external appearance were used, that is, uniform size, intact skin, without mechanical injuries, stains and/ or cracks. Subsequently, the fruits were washed, brushed and sanitized in sodium hypochlorite solution at $100 \mathrm{mg} \mathrm{L}^{-1}$ for 30 minutes and bleached in water at $90{ }^{\circ} \mathrm{C}$ for five minutes. Then, peeling, removing the pyrenes and removing the fruit pulp was performed manually. The removed pulp was immersed in sodium hypochlorite solution at $50 \mathrm{mg}$ $\mathrm{L}^{-1}$ for 30 minutes and then cut into standard slices.

To prepare the flour, the pulp was directed to a dryer with forced air circulation at $60{ }^{\circ} \mathrm{C}$ for six hours. Soon after, the dehydrated pulp was cooled to room temperature and subjected to grinding in a domestic multiprocessor (Philips Walita model
RI7625) until the desired granulometry was reached. The flour was then placed in a tightly closed glass container and stored at $7{ }^{\circ} \mathrm{C}$.

\section{Breaded chicken formulation}

Four breaded chicken formulations were prepared (Table 1), which differed by the composition of the breading ingredients from the pre-flouring stage (predust).

In the formulation of the breaded control (BC) predust, only breadcrumbs (BCF) were contained. In the other formulations, $\mathrm{BCF}$ was substituted with pequi pulp flour (PPF) in 25\% (B25), 50\% (B50), and $100 \%$ (B100).

For the production of breaded, chilled chicken breast fillets were ground in a grinder (Becker Equipamentos Ind. Ltda, model RBT-6) with 10 $\mathrm{mm}$ discs. Subsequently, the fragmented meat was mixed with the other ingredients of the formulation. Immediately after that, the homogeneous meat mass went to the stage of manual modeling acquiring the shape of the nuggets.

After molding, the products proceeded to breading, which was carried out in four stages: 1) immersion in batter liquid; 2) pre-flouring (predust) with $\mathrm{BCF}, \mathrm{PPF}$, or a combination thereof; 3) batter again and finally, 4) flouring (breading) with cornmeal. Breaded products were packed in polyethylene bags and stored at $-2{ }^{\circ} \mathrm{C}$. In order to carry out most evaluations, according to the analytical methods described below, the breaded products were cooked for four minutes in an electric fryer with the use of soybean oil at a temperature of $170{ }^{\circ} \mathrm{C}-180{ }^{\circ} \mathrm{C}$, which was controlled by a thermometer at model TI-550 laser from Instrutherm. 
Table 1

Breaded chicken formulations

\begin{tabular}{|c|c|c|c|c|}
\hline Meat portion formulation (\%) & $\mathbf{B C}^{1}$ & $\mathbf{B 2 5}^{1}$ & B50 $^{1}$ & $\mathbf{B 1 0 0}^{1}$ \\
\hline Chicken breast fillets & 83.00 & 83.00 & 83.00 & 83.00 \\
\hline Emulsifier - sodium tripolyphosphate INS451i² & 0.30 & 0.30 & 0.30 & 0.30 \\
\hline Cornstarch & 3.00 & 3.00 & 3.00 & 3.00 \\
\hline Cold water & 5.00 & 5.00 & 5.00 & 5.00 \\
\hline Textured soy protein & 3.50 & 3.50 & 3.50 & 3.50 \\
\hline Salt & 2.00 & 2.00 & 2.00 & 2.00 \\
\hline Hydrogenated vegetable fat & 1.20 & 1.20 & 1.20 & 1.20 \\
\hline Monosodium glutamate & 0.40 & 0.40 & 0.40 & 0.40 \\
\hline Dehydrated garlic & 0.14 & 0.14 & 0.14 & 0.14 \\
\hline Dehydrated onion, garlic and parsley & 0.51 & 0.51 & 0.51 & 0.51 \\
\hline Ground white pepper & 0.15 & 0.15 & 0.15 & 0.15 \\
\hline Chilli pepper & 0.10 & 0.10 & 0.10 & 0.10 \\
\hline Lemon juice & 0.70 & 0.70 & 0.70 & 0.70 \\
\hline TOTAL & 100 & 100 & 100 & 100 \\
\hline Batter formulation (\%) & $\mathbf{B C}^{1}$ & $\mathbf{B 2 5}^{1}$ & B50 $^{1}$ & $\mathbf{B 1 0 0}^{1}$ \\
\hline Cornstarch & 26.30 & 26.30 & 26.30 & 26.30 \\
\hline Powdered milk & 6.60 & 6.60 & 6.60 & 6.60 \\
\hline Salt & 1.30 & 1.30 & 1.30 & 1.30 \\
\hline Water & 65.80 & 65.80 & 65.80 & 65.80 \\
\hline TOTAL & 100 & 100 & 100 & 100 \\
\hline Breading formulation (\%) & $\mathbf{B C}^{1}$ & $\mathbf{B 2 5}^{1}$ & B50 $^{1}$ & $\mathbf{B 1 0 0}^{1}$ \\
\hline Breadcrumbs (predust) & 50.00 & 37.50 & 25.00 & - \\
\hline Pequi Pulp Flour (predust) & - & 12.50 & 25.00 & 50.00 \\
\hline Cornflour (breading) & 50.00 & 50.00 & 50.00 & 50.00 \\
\hline TOTAL & 100 & 100 & 100 & 100 \\
\hline
\end{tabular}

${ }^{1} \mathrm{BC}=$ Breaded chicken control; B25 = Breaded with $25 \%$ of PPF in predust; B50 = Breaded with $50 \%$ of PPF in predust; B100 = Breaded with $100 \%$ of PPF in predust.

${ }^{2}$ Brand: Conatril SBR Foods Ltda.

\section{Chemical composition}

The chemical parameters of the breaded chicken were obtained based on the methods recommended by the Association of Official Analytical Chemists [AOAC] (2016), in breaded after cooking, with the exception of the lipids that were measured before and after frying. The moisture analysis consisted of the weight loss of the samples in an oven at $105^{\circ} \mathrm{C}$ until they reached constant weight. Protein content was determined using the micro-Kjeldahl method with a correction factor of 6.25. Lipid quantification was performed using the oil and fat extraction technique in a Soxhlet device. The ash analysis was done by muffle incineration at $550{ }^{\circ} \mathrm{C}$, and the total carbohydrates were calculated using a difference, which consists of subtracting the percentages of moisture, protein, lipids and ash from $100 \%$.

\section{Analysis of technological properties}

The technological properties were evaluated based on the changes in volume, mass and color of the breaded before and after frying. 
The specific volume was obtained as the ratio between the apparent volume measured in a measuring cylinder (using millet) and the mass of the breaded, according to equation 01 . The mass yield was calculated by measuring the percentage of how much mass there was in the breaded after frying in relation to the product before the cooking process, and it was obtained by equation 02 (Rajkumar et al., 2014).

$$
\begin{array}{lr}
\text { Specific volume }\left(\mathrm{cm}^{3} \mathrm{~g}^{-1}\right)=\frac{\text { Apparent volume }\left(\mathrm{cm}^{3}\right)}{\text { Mass }(\mathrm{g})} & \{\text { Eq. } 01\}, \\
\text { Mass yield }(\%)=\left(\frac{\text { Mass after cooking process }(\mathrm{g})}{\text { Mass before cooking process }(\mathrm{g})}\right) * 100 & \{\text { Eq. } 02\} .
\end{array}
$$

Konica Minolta portable colorimeter with (Equation 03); Hue angle $\left(\mathrm{h}^{\circ}\right)$ for defining the hue CIELAB system defined by coordinates $L^{*}$ of fried breaded (Equation 04) and the saturation or (luminosity), $a^{*}$ (coordinate red/green), and $b^{*}$ chromaticity of the color of the products after frying (coordinate yellow/blue) was used to obtain the by calculating the Chroma (C) using equation 05. color difference of breaded before and after frying

$$
\text { Color difference }=\sqrt{(\Delta \mathrm{L})^{2}+(\Delta \mathrm{a} *)^{2}+(\Delta \mathrm{b} *)^{2}} \quad\{\text { Eq.3 }\} \text {, where }
$$

$\Delta \mathrm{L}=$ difference of the $\mathrm{L}$ coordinate before and after frying;

$\Delta \mathrm{a}^{*}=$ difference of the $\mathrm{a}^{*}$ coordinate before and after frying;

$\Delta \mathrm{b}^{*}=$ difference of the $\mathrm{b}^{*}$ coordinate before and after frying.

$$
\begin{aligned}
& h^{\circ}=\operatorname{cotg}\left(\frac{b *}{a *}\right) \quad\{4\}, \text { where } \operatorname{cotg}=\text { cotangent. } \\
& C=\sqrt{(a *)^{2}+(b *)^{2}} \quad\{5\}
\end{aligned}
$$

\section{Sensory analysis}

Sensory tests were carried out with prior approval from the Human Research Ethics Committee of UFMG (CAEE: 90758318.2.0000.5149). Sixty untrained tasters participated in the research and were recruited by invitation to the entire academic community. The tasters filled out the Informed Consent Form (ICF) for Research with Human Beings, questionnaire to collect identification data, eating habits and knowledge about the product, in addition to the affective tests forms performed.
Breaded meat were cooked following the procedure described previously. Four samples, one from each treatment, were encoded with three-digit numbers chosen at random and served on disposable plates. A glass containing drinking water was also served used between the sample tests to prevent residual flavors from interfering with the sensory analysis.

The affective tests performed were consumption intention and acceptance. The consumption intention was obtained by means of a hedonic scale of seven points in which the grades ranged from 01 corresponding to the expression "would never eat", 04 to "would eat occasionally" to 07 referring to "would always eat" (Instituto Adolfo Lutz [IAL] , 2008) The acceptance test evaluated how much the judges liked or disliked the product based on the characteristics of appearance, texture, flavor, and global acceptance, using a hedonic scale of nine points with a variation of 01 "I disliked it extremely", 05 "nor I liked it, nor disliked it "until 09“I liked it extremely” (IAL, 2008). 


\section{Experimental planning and statistical analysis}

The experiment was carried out in a completely randomized design (CRD), containing 3 replicates, and the data are presented as mean \pm standard deviation. The results obtained from technological, physical-chemical, and sensory analyses were analyzed statistically using the Sisvar software. Data were subjected to analysis of variance (ANOVA), and when significant, the Tukey's test at $5 \%$ probability was used.

\section{Results and Discussion}

\section{Chemical composition}

Table 2 shows the results of the centesimal composition of chicken breaded. It is observed that the moisture values of the breaded products varied from $47.22 \%$ to $49.81 \%$. The product with $50 \%$ of pequi flour (PPF) was the one with the highest percentage and the formulation with $25 \%$ PPF was the breaded with the least moisture. These levels are similar to those found by Tanamati et al. (2011) in five commercial samples of pre-fried breaded chicken, ranging from $42.56 \%$ to $53.78 \%$ moisture, and to what reported by Mah, Price and Brannan (2008) in breaded chicken control coated with breadcrumbs, checking about $51.50 \%$ moisture.

Table 2

Centesimal composition (\%) of fried breaded chicken and lipid content (\%) of raw breaded

\begin{tabular}{ccccc}
\hline Composition (\%) $\mathbf{~}^{\mathbf{1 , 2}}$ & $\mathbf{B C}^{\mathbf{3}}$ & $\mathbf{B 2 5}^{\mathbf{3}}$ & $\mathbf{B 5 0}^{\mathbf{3}}$ & $\mathbf{B 1 0 0}^{\mathbf{3}}$ \\
\hline Moisture & $48.93 \pm 0.58^{\mathrm{ab}}$ & $47.22 \pm 1.34^{\mathrm{b}}$ & $49.81 \pm 0.56^{\mathrm{a}}$ & $47.88 \pm 0.50^{\mathrm{ab}}$ \\
Ash & $6.51 \pm 0.15^{\mathrm{a}}$ & $6.12 \pm 0.03^{\mathrm{a}}$ & $6.36 \pm 0.12^{\mathrm{a}}$ & $6.15 \pm 0.27^{\mathrm{a}}$ \\
Lipids & $12.38 \pm 0.19^{\mathrm{d}}$ & $18.26 \pm 0.24^{\mathrm{c}}$ & $20.7 \pm 0.71^{\mathrm{b}}$ & $29.37 \pm 1.11^{\mathrm{a}}$ \\
Proteins & $36.24 \pm 2.36^{\mathrm{b}}$ & $30.59 \pm 0.10^{\mathrm{c}}$ & $39.47 \pm 2.20^{\mathrm{ab}}$ & $43.76 \pm 2.69^{\mathrm{a}}$ \\
Total carbohydrates & 44.87 & 45.03 & 33.47 & 20.72 \\
\hline Lipídios (raw breaded) & $1.92 \pm 0.10^{\mathrm{d}}$ & $9.23 \pm 0.05^{\mathrm{c}}$ & $11,76 \pm 0,10^{\mathrm{b}}$ & $20.22 \pm 0.29^{\mathrm{a}}$ \\
\hline
\end{tabular}

${ }^{1}$ Different letters on the same line indicate a significant difference at 5\% significance using the Tukey's test.

${ }^{2}$ Values expressed as mean \pm standard deviation, except total carbohydrates. With the exception of moisture, all data are presented on a dry basis.

${ }^{3} \mathrm{BC}=$ Breaded chicken control; B25 = Breaded with $25 \%$ of PPF in predust; $\mathrm{B} 50=$ Breaded with $50 \%$ of PPF in predust; $\mathrm{B} 100=$ Breaded with $100 \%$ of PPF in predust.

Regarding the ash content, there was no significant difference between treatments, probably due to the similar levels of mineral residue in both the pequi pulp, $1.41 \%-3.09 \%$ (Ribeiro et al., 2014), and in the breadcrumbs, $1.77 \%$ (Núcleo de Estudos e Pesquisas em Alimentação [NEPA], 2011).

The lipid content was higher in samples with higher amounts of PPF, which may have occurred because the pequi pulp has a high amount of fat, as confirmed by Ribeiro et al. (2014) and FariaMachado et al. (2015), who reported values of
$43.22 \%-68.82 \%$ and $78.50 \%$ respectively. It is noteworthy that pequi oil, according to L. G. Oliveira et al. (2017), has oleic acid as the major fatty acid (57.42\%), which makes the product a good source of omega-9, known to be beneficial to health. Albuquerque et al. (2016) found that oleic acid improved the clinical symptoms of mice with sepsis (a problem that leads to inflammatory and metabolic disorders) by preventing liver and kidney damage, and reducing the formation of reactive oxygen species. Liu et al. (2016), in a study on people with 
metabolic syndrome (MS) or at risk of having it on a diet rich in monounsaturated fatty acids (MUFA), it was found that those who consumed a variety of canola oil rich in oleic acid showed a reduction in body fat and blood pressure, markers of MS.

It is suggested that the high content of PPF oleic acid, during the cooking processes of breaded, has not been drastically altered, as studies with oils high in oleic acid applied in frying processes have shown low loss or modification of this component. The work by Akil et al. (2015) concluded that extra virgin olive oils, rich in oleic acid $(72.20 \%$ to $77.20 \%$ ), subjected to $180{ }^{\circ} \mathrm{C}$ heating for cooking French fries for five minutes had only a slight loss of oleic acid $(0.71 \%$ to $3.50 \%)$ in relation to the oil before frying, even in the longest cooking time evaluated ( 75 minutes corresponding to three frying cycles plus the intervals for heating the oil). In the work of Aladedunye and Przybylski (2013), the composition of sunflower oils with high oleic acid content (79.20\% to $85.20 \%$ ) was evaluated, and subjected to heating at $185{ }^{\circ} \mathrm{C}$, for seven hours a day with eight potato frying processes, five minutes each, and repeating this cycle for seven consecutive days, conditions much more extreme than this work, resulted in a reduction of $5.40 \%$ to $8.40 \%$ in the content of oleic acid in relation to the initial content. These results presented reinforce the idea of preserving the levels of oleic acid in breaded with PPF.

In addition, important fat-soluble pigments are dispersed in this oily fraction, such as carotenoids, which represent a total of $32.18 \mathrm{mg} \mathrm{g}^{-1}$ in the pequi pulp according to L. G. Oliveira et al. (2017). According to M. L. Rodrigues, Souza, Lima, Moura and Geraldine (2013), pequi oil at a temperature of $180{ }^{\circ} \mathrm{C}$ has low loss of carotenoids in short frying times, such as the four minutes used for cooking breaded in this study, which is why it is suggested that a large amount of carotenoids were preserved in the breaded produced.
Regarding the content of lipids, comparing the content before and after cooking, note that after frying, there was an increase in the content of lipids in all formulations. It is suggested that the higher levels of lipids in fried breaded made with PPF are not associated with greater oil absorption caused by this flour, but rather with the high fat content existing in the PPF itself, since the differences in the levels of lipids between the raw and cooked breaded in treatments with and without pequi flour were very similar $(8.94 \%$ to $10.46 \%)$. This is an interesting fact, because the pequi flour showed oil absorption characteristics similar to those of the control, made with more traditional flours.

Total carbohydrates ranged from $20.72 \%$ to $44.87 \%$, which on a wet basis would be from $10.80 \%$ to $22.92 \%$, in accordance with the maximum percentage of $30 \%$ of carbohydrates required by current legislation in Brazil (Instrução Normativa $\left.n^{\circ} 6,2001\right)$. It was observed that the decrease in the content of this nutrient in breaded was inversely proportional to the increase in the content of lipids; thus, with the increase in PPF, there was a decrease in the glycidic percentage.

The protein values of breaded products, $30.59 \%$ $43.76 \%$, which on a wet basis correspond to the range of 16.15 to $22.81 \%$, complied with the national legislation in force for breaded products in Brazil (Instrução Normativa $n^{\circ}$ 6, 2001), which determines a minimum content of $10 \%$ protein. It should be noted that the use of PPF in 50\% and 100\% substitution of breadcrumbs increased the protein content of breaded, considering that considerable protein values have already been reported in the pequi pulp, such as $14.69 \%$ in fruits from Tocantins (Alves et al., 2014), and $6.19 \%$ in fruits from the southern region of the Cerrado (Ribeiro et al., 2014), with data expressed on a dry basis. It is further added that these formulations of 50\% and $100 \%$ PPF in a $100 \mathrm{~g}$ portion represent, respectively, the protein Reference Daily Intake (RDI) of $39.62 \%$ and $45.62 \%$ for adults and $58.27 \%$ and $67.09 \%$ for children aged 7 to 10 years (Resolução n 269,2005 ). 


\section{Technological properties analysis}

The breaded while raw had the same specific volume, but after the cooking process, the highest specific volumes measured were from treatments with high percentages of PPF (Table 3). Similar results were observed for the variable "mass yield", since the treatments with pequi flour showed higher values than the control. These results suggest that the PPF allowed greater retention of water vapor inside the breaded, as the predust and breading layers did not break (Lalam, Sandhu, Takhar, Thompson, \& Alvarado, 2013) and thus breaded with pequi had greater expansion. Such behavior can be attributed to the presence of fibers from this flour, which promote greater firmness in breading and prevent the breakage of the product and detachment of the mass during and after frying (Thebaudin, Lefebvre, Harrington, \& Burgeois, 1997; Teruel, GarcíaSegovia, Martínez-Monzó, Linares, \& Garrido, 2014). The presence of dietary fibers in pequis pulps was reported by Ribeiro et al. (2014) with values in the range of $11.87 \%-26.36 \%$, values well above those described in breadcrumbs with only $5.32 \%$ (NEPA, 2011).

Table 3

Results of the analysis of volume, yield and color of breaded chicken

\begin{tabular}{ccccc}
\hline Technological tests & BC $^{3}$ & B25 $^{\mathbf{3}}$ & B50 $^{\mathbf{3}}$ & B100 $^{\mathbf{3}}$ \\
\hline Specific volume - raw $\left(\mathrm{cm}^{3} \mathrm{~g}^{-1}\right)$ & $1.02 \pm 0.04^{\mathrm{a}}$ & $1.06 \pm 0.09^{\mathrm{a}}$ & $1.06 \pm 0.05^{\mathrm{a}}$ & $1.06 \pm 0.07^{\mathrm{a}}$ \\
Specific volume - fried $\left(\mathrm{cm}^{3} \mathrm{~g}^{-1}\right)$ & $1.10 \pm 0.05^{\mathrm{b}}$ & $1.20 \pm 0.08^{\mathrm{ab}}$ & $1.32 \pm 0.10^{\mathrm{a}}$ & $1.33 \pm 0.05^{\mathrm{a}}$ \\
Mass yield $(\%)$ & $90.31 \pm 0.36^{\mathrm{b}}$ & $93.49 \pm 1.63^{\mathrm{a}}$ & $95.23 \pm 0.96^{\mathrm{a}}$ & $95.99 \pm 0.80^{\mathrm{a}}$ \\
Color difference & $12.25 \pm 0.08^{\mathrm{b}}$ & $13.47 \pm 0.17^{\mathrm{ab}}$ & $14.3 \pm 0.35^{\mathrm{ab}}$ & $14.99 \pm 1.53^{\mathrm{a}}$ \\
Chroma & $37.58 \pm 0.27^{\mathrm{c}}$ & $44.05 \pm 0.26^{\mathrm{b}}$ & $45.44 \pm 0.83^{\mathrm{ab}}$ & $48.37 \pm 2.79^{\mathrm{a}}$ \\
Hue angle & $86.87 \pm 0.04^{\mathrm{a}}$ & $84.98 \pm 0.19^{\mathrm{b}}$ & $79.77 \pm 0.08^{\mathrm{c}}$ & $78.54 \pm 0.56^{\mathrm{d}}$ \\
\hline
\end{tabular}

${ }^{1}$ Different letters on the same line indicate a significant difference at $5 \%$ significance using the Tukey's test.

${ }^{2}$ Values expressed as mean \pm standard deviation.

${ }^{3} \mathrm{BC}=$ Breaded chicken control; B25 = Breaded with $25 \%$ of PPF in predust; B50 = Breaded with $50 \%$ of PPF in predust; $\mathrm{B} 100=$ Breaded with $100 \%$ of PPF in predust.

The pequi flour influenced the colorimetric characteristics of the breaded. The difference in color existing in the breaded before and after cooking was smaller in the control breaded. In contrast, the breaded with $100 \%$ PPF used in predust showed a greater color difference. By calculating the Hue angle, it was possible to identify the tones of the breaded, all of which fit with a color tending to yellow $\left(90^{\circ}\right.$ - yellow tint). However, as the content of pequi flour increased in predust, it is noticed that the Hue angles were smaller $\left(0^{\circ}-\right.$ red tint $)$, that is, indicating gradually more orange colors. Allied to this, the chroma values showed more intense colors as there was a greater aggregation of PPF to the breaded.
These results regarding coloring reveal that the presence of PPF chromogenic compounds determined a more intense color on the outside of the breaded, so as the addition of pequi increased, the samples had more color pigments between red and yellow, that is, possibly because of the richness of the carotenoids present in the fruit (Cardoso et al., 2013; Mendonça et al., 2017; M. L. Rodrigues et al., 2013; Saxena, Maity, Raju, \& Bawa, 2012).

\section{Sensory analysis}

The results of the consumption intention test showed no significant difference between treatments, with averages indicating that tasters "would eat 
occasionally" and "would eat frequently" breaded chicken (Table 4). Likewise, it is observed that all the items evaluated in the acceptance test (appearance, texture, flavor and overall evaluation), did not have a statistically significant difference between treatments and that they were accepted between "I liked it slightly" and "I liked it regularly". Thus, it is reinforced that breaded chicken with pequi flour has the potential for consumption and acceptance by the consumer as much as common breaded, besides adding greater nutritional values.

Table 4

Notes of sensory tests of consumption intention and acceptance of breaded chicken

\begin{tabular}{cccccc}
\hline Test $^{1}$ & Aspect & $\mathbf{B C}^{\mathbf{2}}$ & $\mathbf{B 2 5}^{\mathbf{2}}$ & $\mathbf{B 5 0}^{\mathbf{2}}$ & $\mathbf{B 1 0 0}^{\mathbf{2}}$ \\
\hline Consumption intention & - & $5.13^{\mathrm{a}}$ & $4.72^{\mathrm{a}}$ & $5.02^{\mathrm{a}}$ & $5.02^{\mathrm{a}}$ \\
Acceptance & Appearance & $6.80^{\mathrm{a}}$ & $7.02^{\mathrm{a}}$ & $7.25^{\mathrm{a}}$ & $7.47^{\mathrm{a}}$ \\
& Texture & $7.12^{\mathrm{a}}$ & $7.06^{\mathrm{a}}$ & $7.45^{\mathrm{a}}$ & $7.59^{\mathrm{a}}$ \\
& Flavor & $7.55^{\mathrm{a}}$ & $6.88^{\mathrm{a}}$ & $6.92^{\mathrm{a}}$ & $7.02^{\mathrm{a}}$ \\
& Overall evaluation & $7.49^{\mathrm{a}}$ & $7.04^{\mathrm{a}}$ & $7.24^{\mathrm{a}}$ & $7.27^{\mathrm{a}}$ \\
\hline
\end{tabular}

${ }^{1}$ Different letters on the same line indicate a significant difference at $5 \%$ significance using the Tukey's test. ${ }^{2} \mathrm{BC}=$ Breaded chicken control; B25 = Breaded with $25 \%$ of PPF in predust; B50 = Breaded with $50 \%$ of PPF in predust; $\mathrm{B} 100=$ Breaded with $100 \%$ of PPF in predust.

The graph in figure 1 shows the results of the responses on the frequency of consumption of common breaded chicken (nuggets) by the tasters. The most recurring answer was "I rarely eat breaded" chosen by $57.30 \%$ of the total research population, $63.00 \%$ of women, and $44.40 \%$ of men. However, even with this frequency of consumption "rarely", which corresponded in the questionnaire to spending months without consuming breaded, the average scores of the intention to consume (Table
4) showed great interest of the tasters in consuming more frequently the products made by our research (values represented by 4 - "I would eat occasionally" and 5 - "I would eat frequently"). In addition, considering the total number of grades distributed, the percentages of the sum of grades between 4 and 7 ("I would eat occasionally" to "I would always eat") for each formulation varied from $79.63 \%$ to $83.33 \%$. 


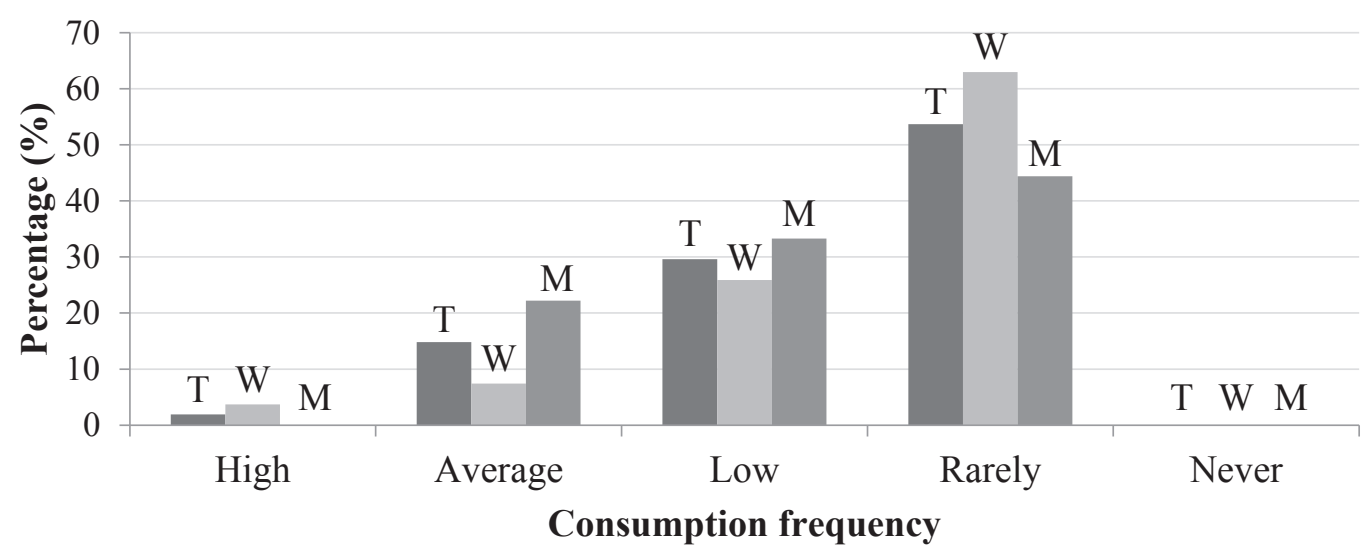

Figure 1. Graph of the percentage of consumption frequency of common breaded chicken (nuggets). $\mathrm{T}=$ Refers to the percentage of consumption considering the total population of tasters; $\mathrm{W}=$ Refers to the percentage of consumption considering only women among the tasters; $\mathrm{M}=$ Refers to the percentage of consumption considering only men among the tasters.

In other sensory studies, the application of pequi byproducts in the creation of new products provided an increase in the acceptance and consumption intention scores. As an example, the margarine test made with pequi oil, in which there was an $80.6 \%$ acceptance rate and $54 \%$ of tasters who "would certainly buy the product" (E. N. A. Oliveira et al., 2011). Cookies formulated with substitution of up to $25 \%$ of wheat flour with the pequi external mesocarp flour, obtained the same acceptance of the standard product (Soares et al., 2009). The global acceptance of pequi sauce showed a frequency of $76 \%$ between the terms "I liked it tremendously" and "I liked it a lot", in addition to $50 \%$ of the tasters reporting that they "would certainly buy" the product (Souza et al., 2014). Such studies only reinforce that the incorporation of pequi in the elaboration of products can be a viable alternative and have the potential to be explored by the food industry.

\section{Conclusion}

The use of pequi pulp flour in predust layer of breaded chicken adds nutritional value to these products, mainly increasing the lipid and protein contents.
In technological evaluations, pequi flour caused higher specific volumes, yields, and more orange tones in the breaded products.

The incorporation of pequi flour in any proportion studied did not negatively alter the sensory characteristics of breaded chicken.

It is concluded that the use of pequi flour in predust of breaded products can provide nutritional and technological enrichment to these products without negatively altering their sensory characteristics.

\section{Acknowledgements}

The authors thank the Grupo de Estudos em Produtos de Panificação e Massas (GEPPAM), the Universidade Federal de Minas Gerais (UFMG), the Pró-Reitoria de Pesquisa (PRPq) da UFMG, the Conselho Nacional de Desenvolvimento Científico e Tecnológico (CNPq), and the Fundação de Amparo à Pesquisa do Estado de Minas Gerais (FAPEMIG).

\section{References}

Aguilar, E. C., Queiroz, M. G. M. N., Oliveira, D. A., \& Oliveira, N. J. F. (2011) Serum lipid profile and hepatic evaluation in mice fed diet containing pequi nut or pulp (Caryocar brasiliense Camb.). Ciência e Tecnologia de Alimentos, 31(4), 879-883. doi: 10.1590/S0101-20612011000400008 
Akil, E., Castelo Branco, V. N., Costa, A. M. M., Vendramini, A. L. A., Calado, V., \& Torres, A. G. (2015). Oxidative stability and changes in chemical composition of extra virgin olive oils after shortterm deep frying of French fries. Journal of the American Oil Chemists' Society, 92(3), 409-421. doi: 10.1007/ s11746-015-2599-2

Aladedunye, F., \& Przybylski, R. (2013). Frying stability of high oleic sunflower oils as affected by composition of tocopherol isomers and linoleic acid content. Food Chemistry, 141(3), 2373-2378. doi: 10.1016/j.foodchem.2013.05.061

Albuquerque, C. F. G., Moraes, I. M. M., Oliveira, F. M. J., Burth, P., Bozza, P. T., Faria, M. V. C.,... Faria Neto, H. C. C. (2016). Omega-9 oleic acid induces fatty acid oxidation and decreases organ dysfunction and mortality in experimental sepsis. PLoS One, 11(4), 1-18. doi: 10.1371/journal.pone.0153607

Alves, A. M., Fernandes, D. C., Sousa, A. G. O., Naves, R. V., \& Naves, M. M. V. (2014). Características físicas e nutricionais de pequis oriundos dos estados de Tocantins, Goiás e Minas Gerais. Brazilian Journal of Food Technology, 17(3), 198-203. doi: 10.1590/1981-6723.6013

Anderson, J. W., Baird, P., Davis, R. H., Jr., Ferreri, S., Knudtson, M., Koraym, A.,... Williams, C. L. (2009). Health benefits of dietary fiber. Nutrition Reviews, 67(4), 188-205. doi: 10.1111/j.1753-4887. 2009.00189.x

Angiolillo, L., Conte, A., \& Del Nobile, M. A. (2015) Technological strategies to produce functional meat burgers. LWT - Food Science and Technology, 62(1), 697-703. doi: 10.1016/j.lwt.2014.08.021

Aschoff, J. K., Kaufmann, S., Kalkan, O., Neidhart, S., Carle, R., \& Schweiggert, R. M. (2015). In vitro bioaccessibility of carotenoids, flavonoids, and vitamin $\mathrm{C}$ from differently processed oranges and orange juices [Citrus sinensis (L.) Osbeck]. Journal of Agricultural and Food Chemistry, 63(2), 578-587. doi: $10.1021 / \mathrm{jf505297 \textrm {t }}$

Association of Official Analytical Chemists (2016). Official Methods of Analysis of AOAC International (20nd ed.), Rockville, MD: AOAC International.

Bailão, E. F. L. C., Devilla, I. A., Conceição, E. C., \& Borges, L. L. (2015). Bioactive compounds found in Brazilian Cerrado fruits. International Journal of Molecular Sciences, 16(10), 23760-23783. doi: 10. 3390/ijms 161023760
Cagdas, E., \& Kumcuoglu, S. (2015). Effects of the addition of grape seed powder on the thermorheological properties of frying batters. International Journal of Food Engineering, 11(2), 185-197. doi: 10.1515/ ijfe-2014-0202

Cardoso, S. L. M., Reis, B. L., Hamacek, F. R., \& Pinheiro-Sant'ana, H. M. (2013) Chemical characteristics and bioactive compounds of cooked pequi fruits (Caryocar brasiliense Camb.) from the Brazilian Savannah. Fruits, 68(1), 3-14. doi: 10.1051/fruits/2012047

Claro, R. M., Santos, M. A. S., Oliveira, T. P., Pereira, C. A., Szwarcwal, C. L., \& Malta, D. C. (2015). Unhealthy food consumption related to chronic noncommunicable diseases in Brazil: national health survey, 2013. Epidemiologia e Serviços de Saúde, 24(2), 257-265. doi: 10.5123/S1679-49742015 000200008

Coutinho, M. A. S., Morais, M. G., Coelho, R. G., Alves, F. V., Fernandes, H. J., Ítavo, C. C. B. F.,... Ribeiro, C. B. (2014). Lipid profile and cholesterol in meat cuts of ewe lambs fed different levels of concentrate. Semina: Ciências Agrárias, 35(6), 3355-3366. doi: 10.5433/1679-0359.2014v35n6p3355

Dishchekenian, V. R. M., Escrivão, M. A. M. S., Palma, D., Ancona-Lopez, F., Araújo, E. A. C., \& Taddei, J. A. A. C. (2011). Padrões alimentares de adolescentes obesos e diferentes repercussões metabólicas. Revista de Nutrição, 24(1), 17-29. doi: 10.1590/ S1415-52732011000100002

Eilat-Adar, S., Sinai, T., Yosefy, C., \& Henkin, Y. (2013). Nutritional recommendations for cardiovascular disease prevention. Nutrients, 5(9), 3646 -3683. doi: 10.3390/nu5093646

Faria-Machado, A. F., Tres, A., Van Ruth, S. M., Antoniassi, R., Junqueira, N. T., Lopes, P. S., \& Bizzo, H. R. (2015). Discrimination of pulp oil and kernel oil from pequi (Caryocar brasiliense) by fatty acid methyl esters fingerprinting, using GC-FID and multivariate analysis. Journal of Agricultural and Food Chemistry, 63(45), 10064-10069. doi: 10.1021/ acs.jafc.5b03699

Gilmore, L. A., Walzem, R. L., Crouse, S. F., Smith, D. R., Adams, T. H., Vaidyanathan, V.,... Smith, S. B. (2011). Consumption of high-oleic acid ground beef increases HDL-Cholesterol concentrations but both high- and low-oleic acid ground beef decrease HDL particle diameter in normocholesterolemic men. The Journal of Nutrition, 141(6), 1188-1194. doi: 10.3945/jn.110.136085 
Gonçalves, G. A. S., Boas, E. V. B. V., Resende, J. V., Machado, A. L. L., \& Boas, B. M. V. (2011). Qualidade dos frutos do pequizeiro submetidos a diferentes tempos de cozimento. Ciência $e$ Agrotecnologia, 35(2), 377-385. doi: 10.1590/ S1413-70542011000200020

Gonçalves, G. A. S., Boas, E. V. B. V., Resende, J. V., Machado, A. L. L., \& Boas, B. M. V. (2010). Qualidade do pequi submetido ao cozimento após congelamento por diferentes métodos e tempos de armazenamento. Revista Ceres, 57(5), 581-588. doi: 10.1590/S0034-737X2010000500003

Instituto Adolfo Lutz (2008). Métodos químicos e físicos para análise de alimentos. São Paulo, SP: Instituto Adolfo Lutz.

Instituto Brasileiro de Geografia e Estatística (2014). Pesquisa Nacional de Saúde: percepção do estado de saúde, estilos de vida e doenças crônicas: 2013. Rio de Janeiro, RJ: IBGE.

Instrução Normativa $n^{\circ}$ 6, de 15 de fevereiro de 2001. Anexo III - Regulamento técnico de identidade e qualidade de empanados. Diário Oficial [da] República Federativa do Brasil, Poder executivo, Brasília, DF, 19 fev. 2001. Seção 1, p. 62.

Jones, P. J. H., Senanayake, V. K., Pu, S., Jenkins, D. J. A., Connelly, P. W., Lamarche, B.,... KrisEtherton. (2014). DNA-enriched high-oleic acid canola oil improves lipid profile and lowers predicted cardiovascular disease risk in the canola oil multicenter randomized controlled trial. The American Journal of Clinical Nutrition, 100(1), 8897. doi: 10.3945/ajcn.113.081133

Klosterbuer, A., Roughead, Z. F., \& Stavin, J. (2011). Benefits of dietary fiber in clinical nutrition. Nutrition in Clinical Practice, 26(5), 625-635. doi: 10.1177/0884533611416126

Kumar, Y., Tanwar, V. K., Pandey, A., Shukla, P., \& Sharma, V. (2017). Development and quality assessment of chicken cutlets enrobed with bread crumbs vis-à-vis dried carrot pomace. Nutrition \& Food Science, 47(5), 700-709. doi: 10.1108/NFS-062016-0082

Lalam, S., Sandhu, J. S., Takhar, P. S., Thompson, L. D., \& Alvarado, C. (2013). Experimental study on transport mechanisms during deep fat frying of chicken nuggets. LWT-Food Science and Technology, 50(1), 110 -119. doi: 10.1016/j.lwt.2012.06.014

Lima, A., Silva, A. M. O., Trindade, R. A., Torres, R. P., \& Mancini, J., Fo . (2007). Composição química e compostos bioativos presentes na polpa e na amêndoa do pequi. Revista Brasileira de Fruticultura, 29(3), 695-698. doi: 10.1590/S0100-29452007000300052

Liu, X., Kris $\square$ Etherton, P. M., West, S. G., Lamarche, B., Jenkins, D. J. A., Fleming, J. A.,... Jones, P. J. H. (2016). Effects of canola and high oleic acid canola oils on abdominal fat mass in individuals with central obesity. Obesity (Silver Spring), 24(11), 2261-2268. doi: 10.1002/oby.21584

Machado, M. T. C., Mello, B. C. B. S., \& Hubinger, M. D. (2013). Study of alcoholic and aqueous extraction of pequi (Caryocar brasiliense Camb.) natural antioxidants and extracts concentration by nanofiltration. Journal of Food Engineering, 117(4), 450-457. doi: 10.1016/j.jfoodeng.2012.12.007

Machado, M. T. C., Mello, B. C. B. S., \& Hubinger, M. D. (2015). Evaluation of pequi (Caryocar brasiliense Camb.) aqueous extract quality processed by membranes. Food and Bioproducts Processing, 95, 304-312. doi: 10.1016/j.fbp.2014.10.013

Mah, E., Price, J., \& Brannan, R. G. (2008). Reduction of oil absorption deep-fried, battered, and breaded chicken patties using Whey Protein Isolate as a postbreading dip: Effect on lipid and moisture content. Journal of Food Science, 73(8), S412-S417. doi: 10.1111/j.1750-3841.2008.00902.x

Mendonça, K. S., Corrêa, J. L. G., Junqueira, J. R. J., Cirillo, M. A., Figueira, F. V., \& Carvalho, E. E. N. (2017). Influences of convective and vacum drying on the quality attributes of osmo-dried pequi (Caryocar brasiliense Camb.) slices. Food Chemistry, 224, 212-218. doi: 10.1016/j.foodchem.2016. 12.051

Miranda-Vilela, A, L., Pereira, L. C. S., Gonçalves, C. A., \& Grisolia, C. K. (2009). Pequi fruit (Caryocar brasiliense Camb.) pulp oil reduces exercise-induced inflammatory markers and blood pressure of male and female runners. Nutrition Research, 29(12), 850858. doi: 10.1016/j.nutres.2009.10.022

Moreira, A. P. B., Teixeira, T. F. S., Alves, R. D. M., Peluzio, M. C. G., Costa, N. M. B., Bressan, J.,... Alfenas, R. C. G. (2016). Effect of a high-fat meal containing conventional or high-oleic peanuts on post-prandial lipopolysaccharide concentrations in overweight/obese men. Journal of Human Nutrition and Dietetics, 29(1), 95-104. doi: 10.1111/jhn.12284

Núcleo de Estudos e Pesquisas em Alimentação (2011). Tabela Brasileira de Composição de Alimentos (TACO) (4a ed). Campinas, SP: NEPA UNICAMP. 
Oliveira, E. N. A., Santos, D. C., Martins, J. N., \& Bezerra, L. C. N. M. (2011). Obtenção e caracterização de margarina convencional e light à base de óleo de pequi. Boletim do Centro de Pesquisa de Processamento de Alimentos, 29(2), 293-304. doi: 10.5380/cep.v29i2.25508

Oliveira, L. A., Reis, R. C., Santana, H. M, Santos, V. S., \& Carvalho, J. L. V. (2017). Development and sensorial acceptance of biofortified dehydrated cassava chips. Semina: Ciências Agrárias, 38(6), 3579-3590. doi: 10.5433/1679-0359.2017v38n6p3579

Oliveira, L. G., Moreno, L. G., Melo, D. S., Costa-Pereira, L. V., Carvalho, M. M. F., Silva, P. H. E.,... Esteves, E. A. (2017) Caryocar brasiliense oil improves cardiac function by increasing Serca2a/PLB ratio despite no significant changes in cardiovascular risk factors in rats. Lipids in Health and Disease, 16(37), 1-8. doi: 10.1186/s12944-017-0422-9

Pinto, L. C. L., Morais, L. M. O., Guimarães, A. Q., Almada, E. D., Barbosa, P. M., \& Drumond, M. A. (2016). Traditional knowledge and uses of the Caryocar brasiliense Cambess. (Pequi) by "quilombolas" of Minas Gerais, Brazil: subsidies for sustainable management. Brazilian Journal of Biology, 76(2), 511-519. doi: 10.1590/15196984.22914

Pinto, M. R. M. R., Paula, D. A., Alves, A. I., Rodrigues, M. Z., Vieira, E. N. R., Fontes, E. A. F., \& Ramos, A. M. (2018). Encapsulation of carotenoid extracts from pequi (Caryocar brasiliense Camb) by emulsification $(\mathrm{O} / \mathrm{W})$ and foam-mat drying. Powder Technology, 339, 939-946. doi: 10.1016/j.powtec. 2018.08.076

Rajkumar, V., Das, A. K., \& Verma, A. K. (2014). Effect of almond on technological, nutritional, textural and sensory characteristics of goat meat nuggets. Journal of Food Science and Technology, 51(11), 3277-3284. doi: 10.1007/s13197-012-0819-4

Resolução $n^{\circ}$ 54, de 12 de novembro de 2012. Regulamento técnico sobre informação nutricional complementar. Recuperado de http://portal.anvisa. gov.br/documents/\%2033880/2568070/rdc0054 12112012 .pdf/c5ac23 fd-974e-4f2c-9fbc$\overline{4} 8 \mathrm{f} 7 \overline{\mathrm{e}} 0 \mathrm{a} 31864$

Resolução $n^{\circ}$ 269, de 22 de setembro de 2005. Regulamento técnico sobre a Ingestão Diária Recomendada (IDR) de proteína, vitaminas e minerais. Recuperado de http://portal.anvisa.gov.br/ legislacao\#/ visualizar/27628
Ribeiro, D. M., Fernandes, D. C., Alves, A. M., \& Naves, M. M. V. (2014). Carotenoids are related to the colour and lipid content of the pequi (Caryocar brasiliense Camb.) pulp from the Brazilian Savanna. Food Science and Technology, 34(3), 507-512. doi: 10.1590/1678-457x.6369

Rodrigues, E. F., Pantoja, L. A., Soares, M. B., Nelson, D. L., \& Santos, A. S. (2016). Development of bouillon cubes from souari nut pulp: formulation and physicochemical and sensorial evaluations. Brazilian Journal of Food Technology, 19(e2015054), 1-8. doi: 10.1590/1981-6723.5415

Rodrigues, L. J., Boas, E. V. B. V., Paula, N. R. F., Pinto, D. M., \& Piccoli, R. H. (2011). Efeito do tipo de corte e de sanificantes no escurecimento de pequi minimamente processado. Ciência $e$ Agrotecnologia, 35(3), 560-567. doi: 10.1590/ S1413-70542011000300018

Rodrigues, M. L., Souza, A. R. M., Lima, J. C. R., Moura, C. J., \& Geraldine, R. M. (2013). Cinética da degradação de carotenoides e da alteração de cor do azeite de pequi submetido ao aquecimento em temperatura de fritura. Ciência Rural, 43(8), 15091515. doi: 10.1590/S0103-84782013000800027

Rodríguez, O., Gomes, W., Rodrigues, S., \& Fernandes, F. A. N. (2017). Effect of acoustically assisted treatments on vitamins, antioxidant activity, organic acids and drying kinetics of pineapple. Ultrasonics Sonochemistry, 35(Part A), 92-102. doi: 10.1016/j. ultsonch.2016.09.006

Rouhani, M. H., Salehi-Abargouei, A., Surkan, P. J., \& Azadbakht, L. (2014). Is there a relationship between red or processed meat intake and obesity? A systematic review and meta-analysis of observational studies. Obesity Reviews, 15(9), 740-748. doi: 10.1111/obr. 12172

Saxena, A., Maity, T., Raju, P. S., \& Bawa, A. S. (2012). Degradation kinetics of colour and total carotenoids in jackfruit (Artocarpus heterophyllus) bulb slices during hot air drying. Food and Bioprocess Technology, 5(2), 672-679. doi: 10.1007/s11947010-0409-2

Silva, V. P., Ferreira, D. N., Souza, N. G. G., Alexandre, A. M., Gomes, I. F. A., \& Moreira, R. T. (2014). Desenvolvimento de sorvetes à base de caldo de cana e avaliação sensorial com crianças. Semina: Ciências Agrárias, 35(2), 813-824. doi: $10.5433 / 1679-0359.2014 \mathrm{v} 35 \mathrm{n} 2 \mathrm{p} 813$ 
Soares, M. S., Jr., Reis, R. C., Bassinello, P. Z., Lacerda, D. B. C., Koakuzu, S. N., \& Caliari, M. (2009). Qualidade de biscoitos formulados com diferentes teores de farinha de casca de pequi. Pesquisa Agropecuária Tropical, 39(2), 98-104. doi: 10.5216/ pat.v39i2.5188

Sousa, A. G. O., Fernandes, D. C., Alves, A. M., Freitas, J. B., \& Naves, M. M. V. (2011). Nutritional quality and protein value of exotic almonds and nut from the Brazilian Savanna compared to peanut. Food Research International, 44(7), 2319-2325. doi: 10.1016/j.foodres.2011.02.013

Souza, J. P., Alves, R. E., Brito, E. S., Lucena, M. N. G., \& Rufino, M. S. M. (2014). Estabilidade de molho de pequi (Caryocar coriaceum wittm) armazenado à temperatura ambiente. Revista Brasileira de Fruticultura, 36(2), 425-432. doi: 10.1590/01002945-127/13

Tamsen, M., Shekarchizadeh, H., \& Soltanizadeh, N. (2018). Evaluation of wheat flour substitution with amaranth flour on chicken nugget properties. LWT - Food Science and Technology, 91, 580-587. doi: 10.1016/j.lwt.2018.02.001

Tanamati, A. A. C., Aguiar, A. C., Boroski, M., Montanher, P. F., Souza, N. E., Godoy, H. T.,... Visentainer, J. V. (2011). Proximate composition and quantification of fatty acids in breaded chicken steak. Ciência e Tecnologia de Alimentos, 31(1), 178-183. doi: 10.1590/S0101-20612011000100026

Teruel, M. R., García-Segovia, P., Martínez-Monzó, J., Linares, M. B., \& Garrido, M. D. (2014). Use of vacuum-frying in chicken nuggets processing. Innovative Food Science and Emerging Technologies, 26, 482-489. doi: 10.1016/j.ifset.2014.06.005
Thandapilly, S. J., Raj, P., Louis, X. L., Perera, D., Yamanagedara, P., Zahradka, P.,.. Netticadan, T. (2017). Canola oil rich in oleic acid improves diastolic heart function in diet-induced obese rats. The Journal of Physiological Sciences, 67(3), 425430. doi: 10.1007/s12576-016-0504-X

Thebaudin, J. Y., Lefebvre, A. C., Harrington, M. H., \& Burgeois, C. M. (1997). Dietary fibres: nutritional and technological interest. Trends in Food Science \& Technology, 8(2), 41-48. doi: 10.1016/S09242244(97)01007-8

Torres, L. R. O., Santana, F. C., Shinagawa, F. B., \& Mancini, J., Fo . (2018). Bioactive compounds and functional potential of pequi (Caryocar spp.), a native Brazilian fruit: a review. Grasas y Aceites, 69(2), e257. doi: 10.3989/gya.1222172

Traesel, G. K., Menegati, S. E., Santos, A. C., Souza, R. I. C., Villas Boas, G. R., Justi, P. N.,... Oesterreich, S. A. (2016). Oral acute and subchronic toxicity studies of the oil extracted from pequi (Caryocar brasiliense Camb.) pulp in rats. Food and Chemical Toxicology, 97, 224-231. doi: 10.1016/j.fct.2016. 09.018

Valente, A., Sanches-Silva, A., Albuquerque, T. G., \& Costa, H. S. (2014). Development of an orange juice in-house reference material and its application to guarantee the quality of vitamin $\mathrm{C}$ determination in fruits, juices and fruit pulps. Food Chemistry, 154, 71-77. doi: 10.1016/j.foodchem.2013.12.053 
